\title{
PENGARUH POLA KOMUNIKASI PIMPINAN TERHADAP KINERJA PEGAWAI PERPUSTAKAAN UNIVERSITAS MATARAM
}

\author{
Lubis, S.Sos.,M.I.Kom, Widiastuti Furbani, S.Sos., M.Si \\ Jurusan IImu Perpustakaan Fakultas IImu Sosial dan IImu Politik Universitas Muhammadiyah Mataram,lubis.vharoso@gmail.com
}

\begin{tabular}{l} 
INFO ARTIKEL \\
\hline Riwayat Artikel: \\
Diterima:02-12-2017 \\
Disetujui:10-01-2018 \\
\hline
\end{tabular}

Kata Kunci:

Pola komunikasi

pemimpin

Komunikasi formal

Komunikasi informal

Proses komunikasi

Bentuk komunikasi

Kinerja pegawai

perpustakaan

\begin{abstract}
ABSTRAK
Abstrak: Pola komunikasi adalah pola hubungan antara dua orang atau lebih dalam pengiriman dan penerimaan pesan dengan cara yang tepat sehingga pesan yang dimaksud dapat dipahami. Setiap pemimpin memiliki pola komunikasi yang berbeda secara pengaplikasian dalam menggerakan organisasinya untuk mencapai tujuan organisasi dan setiap pemimpin akan membangun pola komunikasinya masing-masing sesuai dengan apa yang mereka pahami. Penelitian ini mengkaji tentang pola komunikasi pemimpin secara formal, informal, proses dan bentuk komunikasi terhadap kinerja pegawai di perpustakaan Univesitas Mataram. Metode penelitian yang digunakan dalam penelitian ini adalah pendekatan survey descriptive dan survey explanatory, dengan teknik pengumpulan data yang digunakan adalah angket, wawancara, observasi, dan studi kepustakaan. Populasi saran pada penelitian ini adalah pegawai perpustakaan yang ada di Universitas Mataram sebanyak 126, kemudian penarikan sampel dengan menggunakan rumus Slovin dengan toleransi kesalahan sekitar 0,005 sehingga sampel yang di dapatakan sebanyak 90 orang dan pengujian hipotesis menggunakan analisis jalur (Path Analysis). Hasil penelitian ini menunjukan bahwa pola komunikasi pemimpin baik komunikasi formal, informal, proses dan bentuk komunikasi berpengaruh terhadap kinerja pegawai perpustakaan Universitas Mataram. Jadi, terdapat pengaruh pola komunikasi pemimpin secara positif variabel bebas komunikasi formal, komunikasi informal, proses komunikasi, dan bentuk komunikasi, terhadap variabel terikat kinerja pegawai. Artinya, bila komunikasi formal, komunikasi informal, proses komunikasi, dan bentuk komunikasi meningkat, maka kinerja pegawai jadi meningkat. Bila komunikasi formal, komunikasi informal, proses komunikasi, dan bentuk komunikasi menurun, maka kinerja pegawai jadi menurun juga.
\end{abstract}

\section{A. LATAR BELAKANG}

Komunikasi dalam suatu organisasi erat kaitannya dengan struktur organisasi dipandang sebagai sistem, tempat mengalirnya arus infromasi berada dalam suatu organisasi melalui komunikasi kita bisa berintraksi dengan atasan atau sesama pegawai. Komunikasi menjadi kebutuhan untuk berintraksi pada tiap-tiap individu, membawa manusia pada wujud prilaku sosial, manusia satu dengan lainnya saling membutuhkan dan saling mempengaruhi terutama dalam wujud tujuan kerja agar dapat terealisasinya visi dan misi organisasi. Hal ini akan diperoleh apabila pelaku-pelaku komunikasi di dalamnya menyadari pentingnya interaksi di dalam internal organisasi.

Pola komunikasi merupakan tindakan atau tingkah laku dalam kehidupan sehari-hari memeberi ciri-ciri tertentu dan tanpa disadari itu dipelajari, pola intraksi ini membentuk sistem. Pola intraksi diikuti oleh orang dalam organisasi, pola interaksi itu bukan muncul seketika tetapi telah direncanakan secara matang sebelumnya, karena menentukan suatu pola interaksi komunikasi dalam suatu organsisasi merupakan suatu keharusan, karena pola komunikasi dalam organisasi mengikuti proses penyampean dan penerimaan informasi dalam organisasi mengikuti struktur hierarki merupakan karakteristik dari tiap organisasi

Pola komunikasi merupakan kegiatan komunikasi yang terjadi di dalam organisasi dapat dilihat dari suasana kerja di dalam organisasi tersebut, misalnya cara pegawai berkomunikasi dengan atasan atau sebaliknya, cara individu menyesuaikan diri dengan organisasi sehingga tujuan dari organisasi dapat dicapai.

Dalam kaitanya dengan proses penyampeian informasi dari pimpinan kepada bawahan ataupun dari manajer kepada keryawan, pola transformasinya dapat berbentuk komunikasi formal dan komunikasi informal, (Muhammad, 2011:95).

Menurut Arni Muhammad (2011:4) Komunikasi adalah pertukaran pesan verbal maupun nonverbal antara si pengirim dengan si penerima pesan untuk mengubah tingkah laku.

Pola komunikasi organisasi yang sekarang populer digunakan oleh pemimpin terdiri atas komunikasi formal, komunikasi infromal, proses komunikasi dan bentuk komunikasi. Komunikasi fromal merupakan pesan yang melalui jalan resmi yang ditentukan oleh hierarki resmi organisasi atau oleh fungsi 
pekerjaan maka pesan itu menurut jaringan komunikasi formal. Sedangkan komunikasi infromal terjadi bila karyawan berkomunikasi dengan yang lainnya tanpa memperhatikan posisi mereka dalam organisasi, maka pengarahan arus informasi bersifat pribadi, proses komunikasi merupakan tahapan dan alur komunikasi yang terjadi dalam hirarki organisasi, dan bentuk komunikasi ini merupakan komunikasi yang terjadi dalam organisasi yang berangkat dari etika dan norma yang terjadi di sebuah organisasi itu sendiri. (Muhammad, 2011:107-124).

Pada dasarnya pola komunikasi ini sangat diperlukan oleh seorang pimpinan dalam organisasi, bahwa antara komunikasi formal dan komunikasi infromal dan juga proses komunikasi beserta bentuk komunikasi saling mengisi antara satu dengan lainnya dalam hal pencapai tujuan organisasi (Muhammad, 2011:95)

Dalam kaitanya dengan kemampuan pegawai perpustakaan hendaknya disesuaikan dengan bidang keahlian masing-masing untuk mendukung visi dan misi perpustakaan, sehingga dalam melakukan aktivitas kerjanya pustakawan betul-betul serius dan juga terbangun komunikasi yang baik dalam rangka memperoleh kinerja yang optimal bukan hanya untuk bekerja sebagai bagian dari pemenuhan tanggung jawab saja.

Selanjutnya semua pegawai perpustakaan yang ada dalam struktur organisasi perpustakaan harus dilibatkan dalam interaksi dan juga berkomunikasi, berkonsultasi mengenai semua masalah dalam wilayah kebijakan perpustakaan, tentunya yang relevan dengan kedudukan mereka. Dalam kesempatan ini para pegawai perpustakaan disemua tingkatan harus diberikan kesempatan berkomunikasi dan berkonsultasi dengan demikian mereka diharapkan dapat mampu berperan serta dalam proses pembuatan keputusan dan penentuan tujuan perpustakaan sehingga dangan cara ini setiap pegawai perpustakaan akan merasakan tanggung jawab mendalam pada saat melaksanakan setiap tugas yang diberikan.

Kemudian semua anggota organisasi perpustakaan harus relatif mudah dalam mendapatakan informasi yang berhubungan langsung dengan tugas mereka saat ini dalam rangka mempengaruhi kemampuan mereka untuk mengkoordinasikan pekerjaan mereka dengan orang-orang atau bagianbagian lainnya, misalnya kepada para pemimpin, dan rencan-rencan strategis telah dirumuskan bersamasama untuk selanjutnya dapat memperoleh motivasi dalam meraih kinerja tinggi.

Swasto (1996:34) mengemukakan bahwa prestasi kerja adalah tindakan-tindakan atau pelaksanaan tugas yang telah diselesaikan oleh seseorang berkaitan dengan jumlah kuantitas dan kualitas pekerjaan yang dapat diselesaikan individu dalam kurun waktu tertentu.

Berdasarkan uraian pada latar belakang penelitian sebelumnya, maka permasalahan akan diteliti dapat dirumuskan sebagai berikut: "sejauhmana pengaruh pola komunikasi pemimpin terhadap kinerja pegawai pada Perpustakaan Universitas Mataram

Memperhatikan fenomena dapat ditangkap dalam latar belakang masalah diatas dapat diidentifikasi sebagai berikut:
1. Seberapa besar pola komunikasi formal berpengaruh terhadap kinerja pegawai Perpustakaan Universitas Mataram ?

2. Seberapa besar pola komunikasi informal berpengaruh terhadap kinerja pegawai Perpustakaan Universitas Mataram?

3. Seberapa besar proses komunikasi pemimpin berpengaruh terhadap kinerja pegawai Perpustakaan Universitas Mataram ?

4. Seberapa besar bentuk komunikasi pemimpin berpengaruh terhadap kinerja pegawai Perpustakaan Universitas Mataram ?

Seberapa besar Pola komunikasi formal, infromal, proses komunikasi dan bentuk komunikasi berpengaruh secara simultan terhadap kinerja pegawai perpustakaan Universitas Mataram ?

\section{B. METODE PENELITIAN}

Metode penelitian yang digunakan dalam penelitian ini adalah pendekatan survey descriptive dan survey explanatory. Pendekatan descriptive digunkan untuk memperoleh fakta-fakta, mencari keterangan faktual, serta berusaha untuk menggambarkan gejala-gejala dari praktek yang sedang berlangsung (Nazir, 1985:65) sedang pendekatan explanatory digunakan untuk menjelaskan hubungan kausal melalui pengujian hipotesis antara variabel yang sedang diteliti.

Menurut Rusidi (1992:24) pendekatan explanatory merupakan metode penelitian yang bertujuan untuk menguji hipotesis dengan cara mendasarkan pada pengamatan terhadap akibat yang terjadi dan mencari faktor-faktor yang mungkin menjadi penyebabnya melalui data tertentu.

\section{HASIL DAN PEMBAHASAN}

Penelitian ini menggunakan pendekatan kuantitatf dengan jenis penelitian survey eksplanasi, yaitu suatu jenis penelitian yang tidak hanya menjelaskan suatu suatu fenomena saja akan tetapi juga menjelaskan sejauhmana keterkaitan antar variabel. Dalam konteks penelitian yaitu bertujuan untuk menjelaskan seberapa besar pengaruh komunikasi formal, komunikasi informasi, proses komunikasi serta bentuk komunikasi pemimpin berpengaruh baik secara parsial maupun secara simultan berpengaruh terhadap kinerja pegawai di perpustakaan Universitas Mataram.

Teknik pengumpulan data dilakukan untuk mengumpulkan data primer dan data sekunder. Data primer dalam penelitian ini adalah diperoleh melalui kuesioner yang telah disebarkan kepada pegawai perpustakaan di lingkungan Universitas Mataram baik perpustakaan pusat maupun perpustakaan fakultas maupun perpustakaan lembaga. Jumlah sampel dalam penelitian ini adalah sebanyak 90 orang responden. Data tersebut merupakan data pokok dimana analisisnya ditunjang oleh data 
sekunder yang diperoleh melalui hasil wawancara dengan bagian kepala perpustakaan pusat maupun dengan beberapa pegawai perpustakaan yang ada di lingkungan Universitas Mataram.

Analisis yang akan disajikan dalam penelitian ini terdiri dari tiga bagian yakni analisis data responden, analisis deskriptif dan analisis jalur. Teknik analisis yang digunakan pada analisis data responden dan analisis data penelitian adalah menggunakan analisis deskriptif, dimana semua data yang diperoleh disusun ke dalam tabel melalui perhitungan distribusi dan presentasenya melalui pengolahan data statistik dengan bantuan program SPSS Versi 15.0.

Pengujian hipotesis yang dipergunakan dalam penelitian ini menggunakan analisis jalur (path analisis). Sedangkan variabel kausal adalah pola komunikasi pemimpin yang meliputi aspek, komunikasi formal (X1), komunikasi informal (X2), proses komunikasi (X3) serta bentuk Komunikasi (X4) yang mempengaruhi kinerja pegawai perpustkaan Universitas Mataram (Y).

\section{Gambar 1.1 Diagram Jalur}

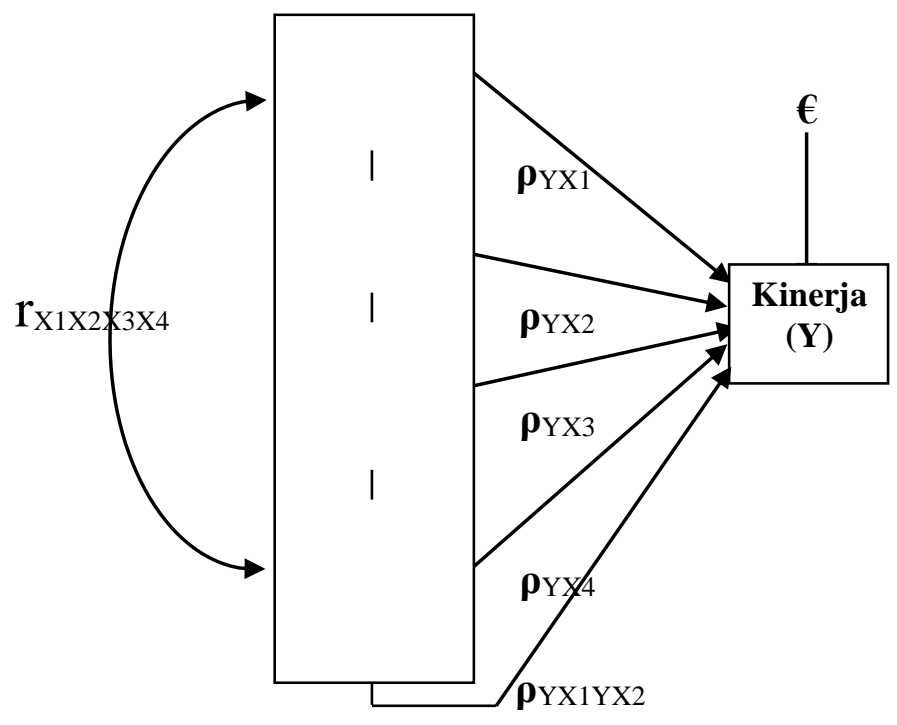

Keterangan :

\begin{tabular}{|c|c|}
\hline $\mathrm{X} 1$ & : Komunikasi formal \\
\hline $\mathrm{X} 2$ & : Komunikasi informal \\
\hline $\mathrm{X}_{3}$ & : proses komunikasi \\
\hline $\mathrm{X}_{4}$ & : Bentuk komunikasi \\
\hline $\mathrm{Y}$ & : Kinerja Pegawai \\
\hline
\end{tabular}
Koefisien jalur yang menggambarkan besarnya pengaruh langsung variabel $\mathrm{X} 1$ terhadap $\mathrm{Y}$.

Berdasarkan hasil analisis data yang telah yang telah dilakukan, penulis menginterpretasikan sebagai berikut:

\footnotetext{
1. Pengaruh pola komunikasi formal $\left(X_{1}\right)$ pemimpin terhadap kinerja pegawai
}

Hasil pengujian statistik menunjukan adanya pengaruh "komunikasi formal $\left(\mathrm{X}_{1}\right)$ " terhadap "kinerja pegawai $(\mathrm{Y})$ ”. secara lebih jelas, besarnya pengaruh langsung "komunikasi formal" terhadap "kinerja pegawai" di perpustakaan Universitas Mataram dapat dilihat pada uraian berikut:

Pengaruh langsung $\mathrm{X}_{1}$ terhadap $\mathrm{Y}=\mathrm{PyX}_{1}$. $\mathrm{PyX}_{1}=$ 0.319

Dari hasil di atas terlihat bahwa besarnya pengaruh langsung antara "komunikasi formal $\left(\mathrm{X}_{1}\right)$ " terhadap "kinerja pegawai (Y)" adalah o.319. Ini berarti pola komunikasi formal pemimpin yang meliputi indikator komunikasi ke bawah, komunikasi ke atas, komunikasi horizontal dan komunikasi diagonal di perpustakaan Universitas Mataram memiliki pengaruh yang signifikan terhadap peningkatan kinerja pegawai.

Hal ini berarti bahwa pola komunikasi formal pemimpin berpengaruh secara signifikan terhadap kinerja pegawai di perpustakaan Universitas Mataram.

Seperti yang telah dijelaskan sebelumnya komunikasi formal terjadi diantara karyawan melalui garis kewenangan yang telah ditetapkan oleh manajemen. Dari kewenangan ini merupakan sistem urat syaraf yang menyediakan saluran-saluran dimana prosedur kerja, instruksi, gagasan, dan umpan balik mengenai pelaksanaan pekerjaan bawahan disampaikan ke bawah dari pimpinan yang lebih tinggi ke karyawan bawahannya. Komunikasi formal juga menetapkan saluran dimana komunikasi ke atas berlangsung, misalnya: bawahan dapat didorong untuk menyatakan ide-ide, sikap, dan perasaan mereka sendiri, pekerjaan mereka, kebijaksanaan perusahaan, dan masalah-masalah sejenis yang melibatkan mereka (Masmuh, 2010:15).

Dalam proses aliran infromasi dalam sebuah organisasi ditentukan oleh hirarki resmi organisasi tersebut, dalam menjalankan fungsi pekerjaan pesan tersebut menurut jaringan komunikasi formal. Pesan dalam jaringan komunikasi formal biasanya mengalir dari atas ke bawah atau dari bawah keatas atau dari tingkatan yang sama atau secara horizontal dan juga secara diagonal. (Masmuh, 2010:15).

Keterampilan komunikasi pemimpin dalam sebuah organisasi merupakan salah satu penentu keberhasilan dalam menjalankan kepemimpinannya, menurut teori ekologi bahwa seseorang pemimpin hanya akan berhasil menjadi pemimpin yang baik jika ia pada waktu lahirnya memiliki bakat-bakat atau sifat-sifat kepemimpinan yang kemudian dikembangkan melalui pendidikan dan pengalaman. Jadi disini ditekankan perlunya pendidikan dan pengalaman untuk bisa menjadi pemimpin yang baik. 
Hasil pengujian statistik menunjukan adanya pengaruh "komunikasi informal (X2)" terhadap "kinerja pegawai (Y)". secara lebih jelas, besarnya pengaruh langsung "komunikasi informal" terhadap "kinerja pegawai" di perpustakaan Universitas Mataram dapat dilihat pada uraian berikut:

Pengaruh langsung X2 terhadap Y = PyX2. PyX2 $=0.208$

Dari hasil di atas terlihat bahwa besarnya pengaruh langsung antara "komunikasi informal (X2)" terhadap "kinerja pegawai (Y)" adalah o.208. Ini berarti pola komunikasi informal pemimpin yang meliputi indikator perilaku karyawan yang selalu berbicara dengan akrab pada waktu-waktu istirahat, perilaku kelompok karyawan yang selalu makan siang bersama di perpustakaan Universitas Mataram memiliki pengaruh yang signifikan terhadap peningkatan kinerja pegawai.

Hal ini berarti bahwa pola komunikasi informal pemimpin berpengaruh secara signifikan terhadap kinerja pegawai di perpustakaan Universitas Mataram.

Melihat pengaruh yang signifikan (0.208) nampaknya pola komunikasi yang terbangun lebih efektif dalam meningkatkan kinerja pegawai perpustakaan. Hal ini sejalan dengan pendapat Abdullah Masmuh (2007:16) bahwa komunikasi informal terjadi diantara karyawan dalam suatu organisasi yang dapat berinteraksi secara bebas satu sama lain terlepas dari kewenangan dan fungsi jabatan mereka. Biasanya komunikasi informal dilakukan melalui tatap muka langsung dan pembicaraan lewat telepon. Komunikasi informal terjadi sebagai perwujudan dari keinginan manusia untuk bergaul (bersosialisasi) dan keinginan untuk menyampaikan informasi yang dipunyainya dan dianggap tidak dipunyai oleh rekan sekerjanya. Meskipun hubungan yang terjadi dalam komunikasi informal ini mengikuti pola yang bebas dari pengaruh organisasi formal, akan tetapi komunikasi informal merupakan saluran yang penting karena menyebar keseluruh bagian dalam organisasi tanpa memperhatikan struktur dan saluran komunikasi formal.

Bahwa pola komunikasi infromal pemimpin pada dasarnya tidak direncanakan dan tidak ditentukan dalam struktur organisasi. Arus infromasi komunikasi informal bersifat pribadi, biasanya dilakukan melalui tatap muka langsung dan pembicaraan lewat telepon. Komunikasi informal lebih berpengaruh karena dalam komunikasi ini terdapat hubungan manusia tanpa melihat struktur sehingga orang merasa dekat dan nyaman dalam berkerja. Dimana kinerja adalah hasil kerja seseorang dalam suatu organisasi selama kurun waktu tertentu sesuai dengan wewenang dan tanggung jawabnya dalam mencapai tujuan dan sasaran tertentu.

\section{Pengaruh proses komunikasi $\left(\mathbf{X}_{3}\right)$ pemimpin terhadap kinerja pegawai}

Hasil pengujian statistik menunjukan adanya pengaruh "proses komunikasi (X3)" terhadap "kinerja pegawai (Y)". secara lebih jelas, besarnya pengaruh langsung "proses komunikasi" terhadap "kinerja pegawai" di perpustakaan Universitas Mataram dapat dilihat pada uraian berikut:

Pengaruh langsung $\mathrm{X}_{3}$ terhadap $\mathrm{Y}=\mathrm{PyX}_{3}$. $\mathrm{PyX}_{3}$ $=0.262$

Dari hasil di atas terlihat bahwa besarnya pengaruh langsung antara "proses komunikasi (X3)" terhadap "kinerja pegawai $(\mathrm{Y})$ " adalah 0.262 . Ini berarti proses komunikasi pemimpin yang meliputi indikator proses komunikasi secara primer, proses komunikasi secara sekunder di perpustakaan Universitas Mataram memiliki pengaruh yang signifikan terhadap peningkatan kinerja pegawai.

Hal ini berarti bahwa proses komunikasi pemimpin berpengaruh secara signifikan terhadap kinerja pegawai di perpustakaan Universitas Mataram.

Melihat pengaruh yang signifikan (0.262) nampaknya proses komunikasi pemimpin yang terbangun lebih efektif dalam meningkatkan kinerja pegawai perpustakaan. Hal ini sejalan dengan pendapat Effendy (2007:11) mengatakan proses komunikasi terbagi menjadi dua tahap, yakni secara primer dan secara sekunder. Secara primer adalah proses penyampaian pikiran dan atau perasaan seseorang kepada orang lain dengan menggunakan lambang (symbol) sebagai media. Lambang sebagai media primer dalam proses komunikasi adalah bahasa, kial, isyarat, gambar, warna, dan lain sebagainya yang secara langsung mampu "menejermahkan" pikiran dan atau perasaan komunikator ke pada komunikan. Bahwa bahasa yang paling banyak digunakan dalam komunikasi adalah jelas karena bahasalah yang mampu "menerjemahkan" pikiran seseorang kepada orang lain. Apakah itu berbentuk ide, informasi atau opini, baik mengenai hal yang kongkrit maupun hal yang abstrak, bukan saja tentang hal atau pristiwa yang terjadi pada saat sekarang, melainkan juga pada waktu yang lalu dan masa yang akan datang. Proses komunikasi secara sekunder adalah proses penyampean pesan oleh seorang kepada orang lain dengan menggunakan alat atau sarana sebagai media kedua setelah memakai lambang sebagai media pertama.

Seorang komunikator menggunakan media kedua dalam melancarkan komunikasinya karena komunikan sebagai sasarannya berada ditempat yang relatif jauh atau jumlahnya banyak. Surat, telepon, teleks, surat kabar, majalah, radio, televisi, flim, dan 
banyak lagi adalah media kedua yang sering digunakan dalam komunikasi.

Bahwa proses komunikasi pemimpin pada dasarnya sebagai cara berkomunikasi dalam rangka mempengaruhi orang lain dikarenakan jarak, dan waktu yang berlansung dalam suatu organisasi. Arus infromasi bersifat simbolik dan kemudian memanfaatkan media sebagai strategi untuk dikomunikasikan lebih lanjut lagi, hal ini biasanya dilakukan melalui kial, isyarat, gambar dan warna kemudian menggunakan media kedua seperti surat, telepon, teleks, surat kabar, majalah, radio, televisi, flim sebagai sarana dalam berkomunikasi. Proses komunikasi ini lebih berpengaruh karena dalam komunikasi ini terdapat hubungan manusia yang lebih luas, fleksibel dan juga efektif tanpa harus terpaku terhadap struktur, sehingga orang merasa dekat dan nyaman dalam berkerja, proses komunikasi pemimpin yang dibangun di perpustakaan menjadi lebih efektif yang akan meningkatkan kinerja pegawai.

\section{Pengaruh bentuk komunikasi $\left(X_{4}\right)$ pemimpin terhadap kinerja pegawai}

Hasil pengujian statistik menunjukan adanya pengaruh "bentuk komunikasi (X4)" terhadap "kinerja pegawai (Y)". secara lebih jelas, besarnya pengaruh langsung "bentuk komunikasi" terhadap "kinerja pegawai" di perpustakaan Universitas Mataram dapat dilihat pada uraian berikut:

Pengaruh langsung $\mathrm{X}_{4}$ terhadap $\mathrm{Y}=\mathrm{PyX}_{4}$. $\mathrm{PyX}_{4}$ $=0.264$

Dari hasil di atas terlihat bahwa besarnya pengaruh langsung antara "bentuk komunikasi (X4)" terhadap "kinerja pegawai (Y)" adalah o.264. Ini berarti bentuk komunikasi pemimpin yang meliputi indikator komunikasi intrapribadi, komunikasi antar pribadi, komunikasi kelompok, komunikasi publik, komunikasi organisasi, komunikasi massa di perpustakaan Universitas Mataram memiliki pengaruh yang signifikan terhadap peningkatan kinerja pegawai.

Hal ini berarti bahwa bentuk komunikasi pemimpin berpengaruh secara signifikan terhadap kinerja pegawai di perpustakaan Universitas Mataram.

Melihat pengaruh yang signifikan (0.264) nampaknya bentuk komunikasi yang terbangun lebih efektif dalam meningkatkan kinerja pegawai perpustakaan. Hal ini sejalan dengan pendapat Mulyana (2005:72-75) yang membagi enam bentuk komunikasi dalam rangka pertukaran pesan verbal maupun nonverbal antara si pengirim dengan si penerima pesan untuk mengubah tingkah laku komunikannya. Komunikasi intrapribadi (intrapersonal communication) adalah komunikasi dengan diri sendiri, baik kita sadari atau tidak, komunikasi antarpribadi (interpersonal communication) adalah komunikasi antar orangorang secara tatap muka, yang memungkinkan setiap pesertanya menangkap reaksi orang lain secara langsung, baik secara verbal ataupun nonverbal, komunikasi kelompok adalah sekumpulan orang yang mempunyai tujuan bersama, yang berinteraksi satu sama lain untuk mencapai tujuan bersama, mengenal satu sama lainnya, dan memandang mereka sebagai bagian dari kelompok tersebut, komunikasi publik (public communication) adalah komunikasi antar seseorang pembicara dengan sejumlah besar orang (khalayak), yang tidak bisa dikenali satu persatu. Komunikasi demikian sering juga disebut pidato, ceramah atau kuliah (umum), komunikasi organisasi (organizational communication) terjadi dalam suatu organisasi, bersifat formal dan juga nonformal, dan berlangsung dalam suatu jaringan yang lebih besar dari pada komunikasi kelompok, komunikasi massa (mass communication) adalah komunikasi yang menggunakan media massa, baik cetak (surat kabar, majalah) atau elektronik (radio, televisi), yang dikelola oleh suatu lembaga atau orang yang dilembagakan, yang ditujukan kesejumlah besar orang yang tersebar dibanyak tempat, anonim, dan heterogenKomunikasi massa (mass communication) adalah komunikasi yang menggunakan media massa, baik cetak (surat kabar, majalah) atau elektronik (radio, televisi), yang dikelola oleh suatu lembaga atau orang yang dilembagakan, yang ditujukan kesejumlah besar orang yang tersebar dibanyak tempat, anonim, dan heterogen.

bahwa komunikasi di atas terjadi diantara karyawan dalam suatu organisasi yang dapat berinteraksi secara bebas satu sama lain dan juga berlangsung secara formal mengikuti struktur organisasi. Biasanya komunikasi di atas dilakukan dengan beragam cara dan bentuknya baik melalui tatap muka langsung dan pembicaraan lewat media massa. Komunikasi di atas terjadi sebagai perwujudan dari keinginan manusia untuk bergaul (bersosialisasi) dan keinginan untuk menyampaikan informasi yang dimilikinya untuk disebarkan baik secara individu maupun secara lebih luas.

Bahwa bentuk komunikasi di atas pada dasarnya ada yang direncanakan dan juga tidak direncanakan yang berlangsung di lingkungan perpustakaan dan juga diluar struktur organisasi. bentuk komunikasi di atas lebih berpengaruh karena dalam komunikasi ini terdapat hubungan manusia antara satu dengan yang lainnya dalam rangka mempengaruhi untuk mencapai kinerja pegawai yang lebih baik di perpustakaan. 


\section{Pengaruh pola komunikasi pemimpin secara bersama-sama (simultan) terhadap kinerja pegawai}

Hasil pengujian secara bersama-sama menunjukan ke empat variabel yaitu komunikasi formal, informal, proses dan bentuk komunikasi berpengaruh secara signifikan terhadap kinerja pegawai. Total pengaruh dari ke empat variabel pola komunikasi pemimpin sebesar 36.0\% dengan kata lain terdapat pengaruh variabel lain $(E 1)$ yakni $100 \%$ $-36.0 \%=64.0 \%$ di luar variabel yang diteliti.

Berdasarkan kesimpulan tersebut, maka dapat dijelaskan bahwa komunikasi yang dilakukan oleh pemimpin di perpustakaan Universita Mataram dinilai mampu mempengaruhi kinerja para pegawai. Hal tersebut dapat terlihat dari respon positif yang diberikan pegawi atas komunikasi yang dilakukan oleh Kepala perpustakaan di Universitas Mataram.

Menurut Arni Muhammad (2011:4) mendifiniskan komunikasi adalah pertukaran pesan verbal maupun nonverbal antara si pengirim dengan si penerima pesan untuk mengubah tingkah laku.

Si pengirim pesan dapat berupa sorang individu, kelompok atau organisasi. Begitujuga halnya dengan si penerima pesan dapat berupa seorang anggota organisasi, seorang kepala bagian, pimpinan kelompok orang dalam organisasi, atau organisasi secara keseluruhan.

Istilah proses maksudnya bahawa komunikasi itu berlangsung melalui tahap-tahap tertentu secara terus-menerus, berubah-ubah, dan tidak ada hentihentinya. Proses komunikasi merupakan proses yang timbal balik karena antara si pengirim dan si penerima saling mempengaruhi satu sama lain.

Perubahan tingkah laku maksudnya dalam pengertian yang luas yaitu perubahan yang terjadi di dalam diri individu mungkin dalam aspek kognitif, afektif atau psikomotor.

Pemimpin sebagai pusat kekuatan dan disiminator bagi organisasi mau tidak mau harus mampu berkomunikasi kepada semua pihak, baik secara formal, informal, beserta proses dan bentuk komunikasi yang dilakukan. Komunikasi adalah salah satu cara membangun hubungan yang lebih baik dalam sebuah organisasi sehingga tercipta komunikasi yang efektif, baik antara pimpinan kepada bawahan maupun antara bawahan kepada pimpinan, juga antara sesama tingkatan, lintas saluran, bantuk komunikasi yang digunakan serta membangun komunikasi informal dalam rangka membangun kekeluargaan di dalam organisasi.

Kemampuan dalam berkomunikasi setiap orang yang bekerja di perpustakaan, baik kepala perpustakaan, maupun staf harus dikuasai dengan baik agar tercipta proses komunikasi yang efektif sehingga menciptakan lingkungan kerja yang kondusif.
Komunikasi pimpinan yang efektif akan mempengaruhi persepsi pegawai terhadap pekerjaannya. Dari sini dapat diketahui bahwa faktor komunikasi pimpinan bagitu berperan dan turut menentukan dalam menciptakan kinerja pegawai yang optimal.

\section{KESIMPULAN}

Pola komunikasi formal, informal, proses serta bentuk komunikasi yang dilakukan pemimpin dalam perpustakaan menyebabkan efektifnya komunikasi di perpustakaan. Pola komunikasi pimpinan yang baik akan berpengaruh terhadap kinerja pegawai perpustakaan itu sendiri. Apabila pola komunikasi sudah efektif akan berdampak positif terhadap fungsi manajemen perpustakaan, kemudian menjadikan visi, misi, tujuan dan sasaran perpustakaan akan berjalan sebagaimana mestinya.

Jadi, terdapat pengaruh pola komunikasi pemimpin secara positif variabel bebas komunikasi formal (X1), komunikasi informal (X2), proses komunikasi ( $\left.\mathrm{X}_{3}\right)$, dan bentuk komunikasi (X4) terhadap variabel terikat kinerja pegawai (Y). Artinya, bila komunikasi formal (X1), komunikasi informal (X2), proses komunikasi (X3), dan bentuk komunikasi (X4) meningkat, maka kinerja pegawai (Y) jadi meningkat. Bila komunikasi formal (X1), komunikasi informal (X2), proses komunikasi (X3), dan bentuk komunikasi (X4) menurun, maka kinerja pegawai $(\mathrm{Y})$ jadi menurun juga.

\section{DAFTAR RUJUKAN}

[1] Arikunto, Suharsimi, 2010. Prosedur Penelitian (Suatu Pendekatan Praktek). Jakarta: PT Rineka Cipta.

[2] Bungin, Burhan, 2005. Metodologi Penelitian Kuantitatif. Komunikasi, Ekonomi dan Kebijakan Publik Serta Ilmu-ilmu Sosial Lainnya. Jakarta: Kencana.

[3] Dharma, Agus, 1985. Manajemen Prestasi Kerja, Rajawali, Jakarta.

[4] Dharma, Surya, 2011. Manajemen Kinerja: Falsafah Teori dan Penerapannya. Yogyakarta: Pustaka Pelajar.

[5] Djamarah, Syaiful Bahri, 2014. Pola Komunikasi Orang Tua dan Anak Dalam Keluarga: Sebuah Perspektif Pendidikan Islam. Jakarta: PT Rineka Cipta.

[6] Effendy, Onong Uchajana, 2007. Komunikasi Teori dan Praktek. Bandung: PT Remaja Rosdakarya Offset.

[7] Gary. A. Yuki, 1998. Kepemimpinan Dalam Organisasi edisi Bahasa Indonesia, Jakarta: PT. Prenkalindo.

[8] Hersey Paul and Blanchard, Kenneth, 1992. Management of Organization Behavior, diterjemahkan oleh Agus Dharmo, Manajemen Perilaku Organisasi, Jakarta: Erlangga.

[9] Kartono, Kartini, 2008. Pemimpin dan Kepemimpinan. Jakarta: PT Raja Grafindo Persada. 
[10]Masmuh, Abdullah. 2010, Komunikasi Organisasi dalam perspektif Teori dan Praktek. Malang: UPT Penerbitan Universitas Muhammadiyah Malang.

[11] Morissan. 2009. Teori Komunikasi Organisasi, Jakarta: Ghalia Indonesia.

[12]Muhammad, Arni. 2011. Komunikasi Organisasi, Jakarta: Bumi Aksara.

[13]Mulyana, Deddy. 2005. Ilmu Komunikasi Suatu Pengantar, Bandung: PT Remaja Rosdakarya Offset.

[14]Pace, Wayne R. And Don F. Faules, 2010. Komunikasi Organisasi: Strategi peningkatan kinerja perusahaan. Editor: Deddy Mulyana, M.A.,PH.D. Bandung: Remaja Rosdakarya.

[15] Prastowo, Andi. 2012. Manajemen Perpustakaan Sekolah Profesional, Jakarta: DIVA Press.

[16]Prijana. 2005. Metode Sampling Terapan untuk Peneliti Sosial, Bandung: Humaniora 